\title{
HYMEN IMPERFORATE: A REPORT OF THREE CASES
}

\author{
Ahmet Ozgur YENIEL, Ahmet Mete ERGENOGLU, Zeynep BAYRAK, Ismail Mete ITIL, Niyazi ASKAR
}

Department of Gynecology and Obstetric, Faculty of Medicine, Ege University, Izmir, Turkey

\begin{abstract}
SUMMARY
Imperforate hymen is a congenital anomaly that is rarely seen in woman genital system. Imperforate hymen is reported $\% 0,1$ of all newborns and it is think that cause of imperforate hymen is congenital defect in the degeneration of central cells of hymen. Although it is generally isolated anomally, sometimes genitourinary anomalies may associate this defect. Patients who has this anomally are generally asymptomatic until puberty and in the period of adolescence, patients administer with a primary amenore and cyclic pelvic pain. History and pelvic examination are the main steps in diagnosis. To determine possible associated anomalies imaging studies are usefull. Treatment of this anomally consist of vaginal reconstrictive surgery. We presented three imperforate hymen cases with literature in this case report.
\end{abstract}

Key word: cyclic pelvic pain, imperforate hymen, puberty

Journal of Turkish Society of Obstetrics and Gynecology, (J Turk Soc Obstet Gynecol), 2011; Vol: 8 Issue: 2 Pages: 140- 3

\section{HIMEN IMPPERFORATUS: ÜÇ OLGU SUNUMU}

\section{ÖZET}

Himen imperforatus kadın genital sisteminde nadir görülen doğumsal bir anomalidir. Yenidoğanlarda sıklı̆ı \% 0,1 olarak bildirilmiștir. Bu patoloji himenin santral hücrelerindeki doğumsal dejenerasyon kusurundan kaynaklanmaktadır. Genellikle izole bir anomali olmakla birlikte, genitoüriner sistem anomalileri ile de birlikte görülebilir. Bu hastalar çoğunlukla puberteye kadar asemptomatik kalabilirler ve adolesan dönem ile birlikte primer amenore ve siklik pelvik ağr s şikayeti ile başvururlar. Bu olgularda anamnez ışığında pelvik muayene tanı koydurucudur. Eşlik eden anomaliler açısından ayrıcı tanıda görüntüleme yöntemleri kullanılabilir. Tedavide cerrahi müdahale gerektirmektedir. Yazımızda himen imperforatus tanılı üç olgu literatür eşliğinde tartışılmışıtır.

Anahtar kelimeler: himen imperforatus, puberte, siklik pelvik ă̆rl

Türk Jinekoloji ve Obstetrik Derneği Dergisi, (J Turk Soc Obstet Gynecol), 2011; Cilt: 8 Sayl: 2 Sayfa: 140- 3

Address for Correspondence: Ahmet Özgür Yeniel. Ege Üniversitesi Kadın Hastalıkları ve Doğum Anabilim Dalı, 35100 Bornova, İzmir Phone: $=90$ (232) 3901730

e-mail: drayeniel@hotmail.com

Received: 11 November 2009, revised: 13 May 2010, accepted: 26 July 2010, online publication: 14 March 2011 


\section{INTRODUCTION}

Imperforate hymen is a rare anomaly of female genital system, and is observed in $0.1 \%$ of newborns ${ }^{(1-3)}$. As a developmental defect, imperforate hymen features degeneration defect in the central cells of hymen. In addition to being usually regarded as an isolated anomaly, it may also co-exist with other genitourinary system anomalies. It may lead to develop hematocolpos by the accumulation of blood in the vagina, hematometra in uterus, and hematosalpinx in tubas. While these patients could remain asymptomatic until puberty, they apply with complaints of primary amenorrhea and cyclic pelvic pain in the adolescent period. Usually a late diagnosis is established, and it is adequate to observe a swollen hymen with purple highlights by a simple genital examination to be performed in all the age groups ${ }^{(4)}$. It usually manifests itself as sporadic cases; however, family inheritance has been defined as well(1).

One of the reasons for the lower abdominal pain in premenarchal girls is imperforate hymen ${ }^{(2)}$. Sometimes, these patients may also apply with complaints of back pain, urinary system symptoms, and constipation(5). Hematocolpos can be occasionally mixed up with pelvic masses. Complaints of pain while urinating and a sudden need to urinate are presented due to the pressure applied to the urinary bladder and urethra. These symptoms are recorded in $58 \%$ of patients with hematocolpos ${ }^{(6)}$.

\section{Case 1}

A 17-year-old patient was referred to our clinic upon determining an ovarian cyst in the medical center, where she had applied to due to the complaint of delayed menstruation. No particular features were recorded in the personal and family history of the case. In her physical examination, secondary sex characters were detected to have developed (Tanner stage 4). In the gynecological examination, it was noted that no hymenal opening was present, and a swollen hymen with purple highlights was revealed, which closed the vagina by forming a curtain around. In the ultrasonographical examination of the patient, a hypoechoic cystic formation with smooth contours that was measured approximately $10 \mathrm{~cm}$ in diameter, was observed along the pelvic midline. In the pelvic magnetic resonance imaging (MRI), an appearance consistent with hematocolpos was recorded. Bilateral ovaries and uterus were identified to be normal (Figure 1). Urinary system was determined to be normal in the intravenous pyelography (IVP) performed for the case. In the laboratory examinations, following values were obtained: $\beta$ Hcg $<0,100 \mathrm{MIU} / \mathrm{ml}$, Leukocyte: 6990/mm³ , Htc: 44.8\%, Hb: 14.1 g/dl, Thrombocyte: $362000 / \mathrm{mm}^{3}$. Case underwent a hymenotomy procedure, and approximately $300 \mathrm{cc}$ of dark-colored, tarry menstrual blood was aspirated. Case was discharged and in the following examination carried out 1.5 months later, it was determined that she started to menstruate and had no complaints.

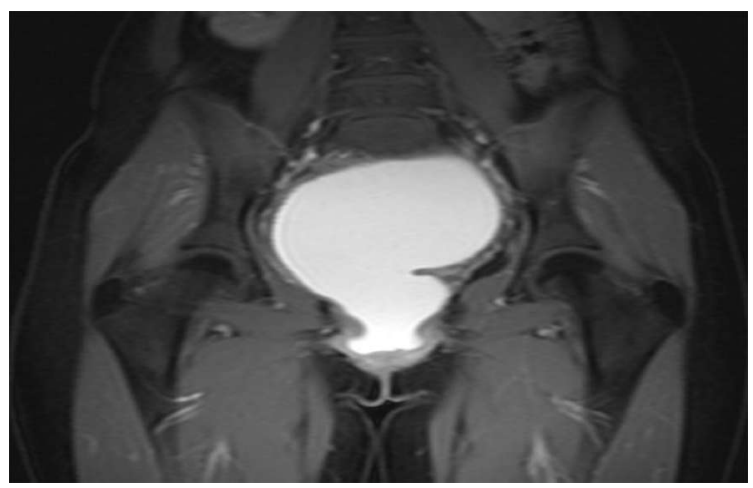

Figure 1: MRI image of hematocolpos on coronal plane.

\section{Case 2}

A 10-year-old patient applied to our clinic with the complaint of abdominal pain. No particular features were recorded in the personal and family history of the case. Vital findings were detected to be normal in her physical examination. In the examination for secondary sex characters, breast development, and axillary and pubic hair growth were consistent with grade 2 according to the Tanner grading system. In the genital examination of the case with no menstrual period so far, it was recorded that no hymenal opening was present, and a swollen hymen with purple highlights was revealed, which closed the vagina by forming a curtain around. In the pelvic ultrasonography, uterus and the right ovary were normal; however, left ovary could not be observed clearly.

A dark-colored cystic formation of $82 \times 72 \mathrm{~mm}$ compatible with hematocolpos was noted along the pelvic midline. In the magnetic resonance imaging (MRI), a giant cystic lesion showing leveling within, which substantially caused expansion, depending on the blood products at different stages was observed in vagina along the pelvic midline. This lesion was $13 \times 8$ 
$\mathrm{cm}$ in sizes and considered as hematocolpos. Uterus and bilateral ovaries appeared normal. No urinary system anomaly was identified in the intravenous pyelography (IVP). In the laboratory examination, following values were obtained: FSH: $1.58 \mathrm{mIU} / \mathrm{ml}$, LH: $0.355 \mathrm{mIU} / \mathrm{ml}$, Estradiol $142 \mathrm{pg} / \mathrm{ml}$, Progesterone $4.83 \mathrm{ng} / \mathrm{ml}$, CA 125:276 U/ml, Leukocyte: $9130 / \mathrm{mm}^{3}$, htc:36.6\%, hb:11.7 g/dl. Performing a cruciform hymenotomy under general anesthesia, approximately $250 \mathrm{cc}$ old blood was aspirated. Case was discharged on the next day, and in the following examination carried out 1.5 months later, she indicated that she menstruated normally and had no complaints.

\section{Case 3}

A 15-year-old patient was referred to our clinic upon determining imperforate hymen in an external center, where she had applied to with complaints of abdominal and back pain. A history of scoliosis was present in the personal history of the case, but no particular features were determined in her family history. Vital findings were normal in her physical examination. In the gynecological examination performed, imperforate hymen with purple highlights was revealed. In the rectal touch, a fluctuating mass with smooth contours that was measured approximately $15 \mathrm{~cm}$ was palpated along the pelvic midline. In the ultrasonographic examination, a dark-colored mass lesion of $12 \times 15 \mathrm{~cm}$ in size was observed; however uterus and ovaries could not be identified clearly. In the laboratory examination, following values were obtained: Leukocyte: $8270 / \mathrm{mm}^{3}$, Htc: 37\%, Hb: 12 g/dl, Thrombocyte: 212000/mm ${ }^{3}$. Case underwent a hymenotomy procedure under general anesthesia, and approximately 1000 cc of tarry menstrual blood was aspirated. The patient was discharged on the next day. In her examination performed 1.5 months later, no problems were detected and she implied to have menstruated.

\section{DISCUSSION}

The incidence of imperforate hymen in newborns has been reported as $\% 0,1^{(1-3)}$. It is a developmental anomaly, which originates from the congenital degeneration defect within the central cells of hymen. Cases with imperforate hymen can remain asymptomatic until puberty, and they apply with complaints of primary amenorrhea and cyclic pelvic pain in puberty. One of the rarely recorded reasons for the lower abdominal pain during adolescent period is imperforate hymen ${ }^{(2)}$. Although a physical examination based on anamnesis and inspection is sufficient for diagnosis, these cases may go unnoticed until the onset of menstruation ${ }^{(4)}$. Thus, cases with imperforate hymen may apply with different clinical conditions such as back pain, urinary symptoms and constipation ${ }^{(5)}$. In the case presentation by Gyimadu et al., urinary catheterization was performed for a case applied to the emergency service with complaints of pelvic pain and inability to urinate for 24 hours due to acute urinary retention ${ }^{(7)}$. In the further examinations of the same case, imperforate hymen was detected and the regression of urinary symptoms was ensured performing a hymenotomy procedure by cruciform incisions. A similar case was presented by Adal1 et al. as well. In the pelvic magnetic resonance imaging of the case with complaints of difficulty while urinating, dysuria and pelvic pain the case had been suffering for one month, imporforate hymen was identified and a hymenotomy procedure was performed. No complaints were recorded in the case followed-up for 6 months ${ }^{(8)}$.

Apart from cruciform incision, another method defined in the treatment is the radial incision technique. In a study conducted by Chelli et al., radial incision technique was applied on 3 out of 5 cases with imperforate hymen in accordance with the hymenal structure. Upon the request of families of other cases regarding the preservation of hymenal structure, a hymenotomy procedure with simple excision was performed and Foley catheter was inserted. Intact hymenal structure was acquired in methods where hymen was preserved. With the conventional radial incision technique being a simple technique which provides good results, the Foley catheter technique is presented as an adequate alternative technique for these cases in such conditions where hymen is intended to be preserved ${ }^{(9)}$.

There are also cases with imperforate hymen in the literature, which are diagnosed in prenatal period. Tseng et al. presented a 32-year-old primigravid case where a retrovesical fetal pelvic mass was identified in the ultrasonographic examination performed at the $36^{\text {th }}$ gestational week. In the fetal magnetic resonance imaging, protrusion of hymen into introitus depending on the fluid accumulation was observed, and the fetal 
diagnosis of imperforate hymen in intrauterine life was established. Fetus who developed hydronephrosis depending on pressure on the postpartum day 2 underwent hymenotomy ${ }^{(10)}$. In the case presentation by Bhargava and Dighe, a case of imperforate hymen was presented, which was identified with fetal pelvic mass in the ultrasonography performed at the gestational week $^{(11)}$. Lim et al., on the other hand, indicated a case with identified familial imperforate hymen ${ }^{(1)}$. Our cases applied during the adolescent period. Cruciform incision technique was used in cases, and aspiration was performed following the incision procedure. Cases with imperforate hymen are usually diagnosed lately. Therefore, the diagnostic period of cases is long and demanding. Bearing this congenital anomaly in mind, which is rarely recorded during the systemic examinations performed in newborns, will ensure the early diagnosis of cases and avoid the need for numerous unnecessary examinations

\section{REFERENCES}

1. Lim YH, Ng SP, Jamil MA. Imperforate hymen: Report of an unusual familial occurrence. J. Obstet. Gynaecol. Res. 2003; 29 No.6: 399- 401

2. Kumar K, Waseem M. An uncommon cause of abdominal pain in an adolescent. Southern Medical Jornal. 2008; 101(10): 1065- 6 .

3. Walsh B, Shih R. An unusual case of urinary retantion in a competitive gymnast. J Emerg Med. 2006; 31: 279- 81.

4. Posner JC, Spandorfer PR. Early detection of imperforate hymen prevents morbiditiy from diagnosis. Pediatrics. 2005; 115: 1008- 112

5. Wang W, Chen MH, Yang W, Hwang DL. Imperforate hymen presenting with chronic constipation and lumbago: report of one case. Acta paediatr Taiwan. 2004; 45: 340- 2.

6. Chircop R. A case of retantion of urine and hematocolpometra. Eur. J Med. 2003; 10: 244- 5.

7. Gyimadu A, Sayal B, Guven S, Gunalp GS. Hematocolpos causing severe urinary retantion in adolescent girl with imperforate hymen: An uncommon presentation. Arch Gynecol Obstet. 2009; 280: 461- 3 .

8. Adali E, Kurtoglu M, Yildizhan R, Kolusari A. An overlooked cause of acute urinary retantion in an adolescent girl: A case report. Arch Gynecol Obstet. 2009; 279: 701- 3.

9. Chelli D, Kehila M, Sfar E, Zouaoui B, Chelli H, Chanoufi B. Imperforate hymen : Can it be treated without damaging the hymenal structure? Sante. 2008 Apr-Jun; 18(2): 837.

10. Tseng JJ, Ho JY, Chen WH, Chou MM. Prenatal diagnosis of isolated fetal hydrocolpos secondary to congenital imperforate hymen. J Chin Med Assoc. 2008 Jun;71(6): 325- 8.

11. Bhargava P, Dighe M. Prenatal US diagnosis of a congenital imperforate hymen. Pediatr Radiol. 2009 Sep; 39(9): 1014. Epub 2009 Mar 21. 